ROCZNIKI FILOZOFICZNE

Tom LXVIII, numer $4-2020$

DOI: https://doi.org/10.18290/rf20684-9

MICHAŁ CHABEREK

\title{
SKĄD POCHODZĄ NOWE FORMY SUBSTANCJALNE? — POLEMIKA Z TEISTYCZNYM EWOLUCJONIZMEM W UJĘCIU MARIUSZA TABACZKA
}

\section{WSTĘP}

Pytanie, które stawiamy $\mathrm{w}$ tym artykule dotyczy tego, czy można być zwolennikiem teistycznego ewolucjonizmu i metafizycznych zasad św. Tomasza z Akwinu jednocześnie? Niedawno ukazał się polski przekład pracy zbiorowej Ewolucja w świetle wiary. Perspektywa tomistyczna, w której promuje się tezę jakoby nauczanie Akwinaty nie tylko było zgodne $\mathrm{z}$ ideą makroewolucji biologicznej, ale nawet w jakiś sposób ją popierało ${ }^{1}$. Dr Mariusz Tabaczek napisał posłowie do tej publikacji, w którym wskazał na pewne braki w argumentacji autorów jednocześnie zaznaczając, że zgadza się z ich zasadniczą tezą.

W niniejszym artykule nie będę zajmował się książką amerykańskich dominikanów, ponieważ udzieliłem całościowej odpowiedzi na ich argumenty w książce Śs. Tomasz z Akwinu a ewolucja². Wykazałem tam, że nie da się jednocześnie być zwolennikiem teistycznego ewolucjonizmu i zasad filozoficznych św. Tomasza. W swoim posłowiu Tabaczek prezentuje przeciwną tezę. Twierdzi, że można, ale pod warunkiem, że zmodyfikuje się naukę św. Tomasza w czterech ,istotnych aspektach”. Samo takie ujęcie może budzić wątpliwości. Jeżeli bowiem Tomasza trzeba istotnie modyfikować, aby po-

Dr Micha£ Chaberek OP — pracownik Fundacji En Arche i współpracownik Discovery Institute (Seattle, USA); doktor teologii fundamentalnej (UKSW); adres do korespondencji: ul. Dominikańska 2, 02-741 Warszawa; email: mckop@dominikanie.pl; ORCID: https://orcid.org/ 0000-0001-8071-537X.

${ }^{1}$ Nicanor P. G. Austriaco i in., Ewolucja w świetle wiary. Perspektywa tomistyczna (Poznań: W drodze, 2019).

${ }^{2}$ Mariusz Chaberek, Św. Tomasz z Akwinu a ewolucja (Kęty: Marek Derewiecki, 2019). 
godzić go z ewolucją, to oznacza, że nie można go pogodzić. Być może problem sprowadza się więc do pytania, czy te cztery punkty niezgodności wskazane przez Tabaczka, rzeczywiście stanowią jakąś ,istotną” część nauki Akwinaty? Jeżeli nie stanowią, to można by je pominąć lub zmodyfikować. Jeżeli dotyczą jednak jakichś istotnych elementów metafizyki arystotelesowsko-tomistycznej, to rezygnacja z nich oznacza zaprzeczenie nauce Tomasza, a tym samym niemożliwość pogodzenia go z teistycznym ewolucjonizmem.

Aby rozstrzygnąć to zagadnienie, w pierwszej części mojego artykułu (1) rozważę, czy punkty przedstawione przez Tabaczka dotyczą istotnych elementów nauczania Akwinaty. W drugiej części (2) przejdę jednak do ważniejszej kwestii. Otóż teistyczny ewolucjonizm napotyka dużo więcej problemów w kontekście metafizyki tomistycznej. Ponieważ pisałem o nich już w kilku miejscach ${ }^{3}$, w drugiej części mojego artykułu ograniczę się jedynie do jednego takiego problemu, czyli powstawania nowych form substancjalnych (nowych gatunków) na drodze ewolucji. Zatem zastanowimy się, czy rozwiązanie, które proponuje Tabaczek, wyjaśnia problem pochodzenia nowych form substancjalnych w teistycznym ewolucjonizmie.

\section{KOMENTARZ DO CZTERECH PUNKTÓW NIEZGODNOŚCI}

Zdaniem Tabaczka naukę Tomasza można pogodzić z teistycznym ewolucjonizmem pod warunkiem:

(1) uznania możliwości powstawania nowych gatunków, a więc tego, że doskonałość wszechświata może co dzień powiększać się nie tylko pod względem liczby jednostek, lecz także pod względem liczby gatunków; (2) podkreślenia tego, że pierwotny akt stwórczy Boga ogranicza się do wyprowadzenia z nicości (ex nihilo) materii o najniższym stopniu złożoności; (3) uznania tego, że procesy ewolucji chemicznej, biochemicznej i biologicznej należą do dzieła upiększenia (opus ornatus), którego kolejne etapy rozciągają się na całą historię wszechświata, a więc nie ograniczają się do zamkniętego i należącego do przeszłości przedziału czasowego; oraz (4) uznania braku konieczności bez-

\footnotetext{
${ }^{3}$ Michał Chaberek, „Classical Metaphysics and Theistic Evolution: Why Are They Incompatible?" Studia Gilsoniana 8, nr 1 (2019): 47-81; Chaberek, Św. Tomasz, 46-55; ChabereK, „Tomasz z Akwinu a teistyczny ewolucjonizm”, Zeszyty Naukowe KUL 59, nr 1 (2016): 59-82; Chaberek, „Pochodzenie człowieka. O filozoficznych problemach hominizacji”, w: Spór o poczatek i koniec życia ludzkiego (Lublin: Polskie Towarzystwo Św. Tomasza z Akwinu, 2015), 221-255.
} 
pośredniej interwencji Boga w powstaniu pierwszych przedstawicieli gatunków roślinnych i zwierzęcych (z wyjątkiem człowieka) ${ }^{4}$.

Ad 1 i 3. Punkty 1 i 3 sprowadzają się do jednego, bowiem w obu chodzi o to, że ewolucja trwa nadal, natomiast w chrześcijańskim ujęciu stworzenie się zakończyło. Jeżeli więc przyjmuje się teistyczny ewolucjonizm, to trzeba odrzucić prawdę chrześcijańską o tym, że Bóg zakończył swoje dzieło stwórcze wraz ze stworzeniem człowieka. Problem polega na tym, że nie jest to prawda filozoficzna, lecz ściśle religijna, czyli objawiona przez Boga. Oczywiście badania naukowe, takie jak znajdujemy w geologii i paleontologii, mogą nam dostarczyć nieco szczegółów historycznych, ale same z siebie nie wyjaśniają początków świata, gatunków i człowieka. Zatem w tym punkcie znajdujemy konflikt teistycznego ewolucjonizmu nie tyle $\mathrm{z}$ metafizyką Tomasza, lecz raczej z czymś bardziej fundamentalnym, to znaczy z wiarą chrześcijańską tak jak Kościół odczytywał ją przez wieki. Prawda mówiąca, że stworzenie zakończyło się nie jest myślą spotykaną tylko u Akwinaty, choć - jak w przypadku innych prawd wiary - wyraża ją w sposób precyzyjny. Tomasz mówi na przykład, że po zakończeniu stworzenia mogą powstawać nowe jednostki danych gatunków, ale nie nowe gatunki ${ }^{5}$. Oczywiście trzeba nieustannie pamiętać, że w dyskusjach na temat makroewolucji mamy na myśli gatunki w szerszym rozumieniu niż gatunek biologiczny. Chodzi o zupełnie nowe natury, tak różne jak pies, kot, koń czy małpa. Tomasz powtarza za Pismem Świętym i tradycyjną teologią, że stworzenie zakończyło się właśnie w sensie powstawania tego typu absolutnych nowości. Należy zauważyć, że również nauki przyrodnicze wskazują na dewolucję $\mathrm{i}$ entropię a nie powstawanie istotnych nowości w świecie. To, co obserwujemy w biologii, to jedynie specjacja, czyli powstawanie gatunków biologicznych. Taki proces można prześledzić zarówno w laboratorium jak i przyrodzie. Jednak powstawanie nowych ras, odmian czy szczepów nie dowodzi tego, że powstają zupełnie nowe formy życia. Zresztą specjacja zachodzi głównie przez dewolucję, czyli zubożenie biologiczne populacji ${ }^{6}$. Zatem to twierdzenie teistycznego ewolucjonizmu nie tylko stoi w sprzeczności z prawdą chrześcijańską, której broni Tomasz, ale również rozmija się z faktami przyrodniczymi.

\footnotetext{
${ }^{4}$ Mariusz TABaczeK, Posłowie do Nicanor P. G. Austriaco i in., Ewolucja w świetle wiary. Perspektywa tomistyczna, 225-241.

${ }^{5}$ „Coś może być dodane każdego dnia do doskonałości świata jeśli chodzi o liczbę jednostek, ale nie jeśli chodzi o liczbę gatunków" (STh, I q. 118 a. 3 ad 2).

${ }^{6}$ Obszerną analizę tego zjawiska przeprowadza Michael J. BEHE w książce Darwin Devolves (New York: HarperOne, 2019).
} 
Ad 2. Drugi punkt jest bezprzedmiotowy, ponieważ Tomasz nie twierdzi niczego poza tym, co Tabaczek określa tutaj jako punkt niezgodności. Dla Tomasza pierwszy akt stwórczy (prima creatio) to właśnie wyprowadzenie z nicości jakiejś pierwotnej materii o nieokreślonej formie. Kształtowanie tej materii Tomasz przypisuje drugiemu stworzeniu (secunda creatio), czyli dziełu rozróżnienia i ozdobienia ${ }^{7}$. W obrazie powstania świata, który prezentuje nam nauka, również obserwujemy stopniowy wzrost złożoności bytów na przestrzeni czasu. Taka wizja koresponduje z teologiczną koncepcją drugiego stworzenia (opus distinctionis, opus ornatus). Zatem i w tym przypadku widzimy jak tradycyjna nauka chrześcijańska zgadza się w swoich istotnych elementach z danymi dostarczanymi przez współczesną naukę.

Ad 4. Czwarty punkt również nie różni się od 1 i 3, ponieważ przekonanie, że nadal powstają gatunki oznacza po prostu tyle, że dzieło stworzenia się nie zakończyło. Zatem stosuje się tutaj ta sama odpowiedź, co w przypadku punktu 1 i 3. Traktuję jednak ten punkt osobno, ponieważ autor popełnia tutaj jeszcze jeden popularny błąd polegający na pomyleniu dzieła stwórczego $\mathrm{z}$ Boską interwencją. Wyjaśnijmy pokrótce na czym polega ten błąd.

Otóż interwencja (łac. inter-venio, wejść pomiędzy) to wejście Boga w jakiś ciąg przyczynowo-skutkowy w celu zmiany jego wyniku. Tak na przykład w zwiastowaniu Bóg posługując się przyczyną wtórną (której rolę pełni anioł Gabriel) przychodzi do Maryi, aby zmienić koleje jej życia a zarazem bieg ludzkiej historii. Podobnie interwencjami są różnorakie cuda uzdrowień, w których dzięki Bożemu nadprzyrodzonemu działaniu zmieniają się ludzkie losy. Interwencją było wstrzymanie słońca nad Gibeonem, dzięki czemu Izraelici mogli odnieść kompletne zwycięstwo i podobnie interwencją był cud słońca nad Fatimą, w wyniku którego nawróciło się wielu ateistów. Jednak w dziele stworzenia nie ma interwencji, ponieważ Boski akt stwórczy nie jest wejściem w ciąg przyczynowo-skutkowy, lecz raczej rozpoczęciem takiego ciągu. Interwencja zakłada istnienie przyczyn i skutków, natomiast stworzenie nie zakłada żadnego istnienia (lub zakłada nicość). Dopóki nie było danego gatunku, to nie było żadnego ciągu przyczynowo-skutkowego z jego udziałem. Stworzenie danego gatunku nie stanowiło interwencji, lecz dodanie nowego rodzaju bytu. Oczywiście wraz ze stworzeniem nowego

\footnotetext{
${ }^{7}$ Tomasz wyróżnia pierwsze stworzenie oraz drugie stworzenie, czyli nadprzyrodzone kształtowanie świata na przestrzeni czasu, który Księga Rodzaju nazywa sześcioma dniami. Drugie stworzenie dzieli się na dzieło rozróżnienia (opus distinctionis) i dzieło upiększenia (opus ornatus). Zob. STh, I q. 65-74, De pot, q. 3 a. 18 arg. 12 oraz ad 11 . Także SS, lib. 2 d. 12 q. 1 a. 5 co.; SS, lib. 2 d. 15 q. 1 pr.; De pot, q. 5 a. 9 ad 8.
} 
gatunku momentalnie wchodzi on w liczne łańcuchy przyczynowo-skutkowe. I dlatego, gdy Bóg przemawia do proroka ustami oślicy, to jest to interwencja, ale stworzenie gatunku koniowatych nie jest.

Odnośnie do czwartego punktu, należy także zapytać, na jakiej podstawie Tabaczek ogranicza Boskie bezpośrednie działania stwórcze do jedynie dwóch momentów, to jest pierwszego stworzenia (creatio ex nihilo) i stworzenia ludzkiej duszy. Jak już zaznaczyliśmy, nauka nie mówi nam jak powstały gatunki, lecz jedynie, $\dot{z} e$ powstały. Paleontologia może nam wskazać, kiedy jakie gatunki zaczęły istnieć, być może w jakich ilościach i jak dużo czasu upłynęło zanim wymarły. Jednak samego pochodzenia gatunków nauka nie wyjaśnia. Zatem nie ma takich danych naukowych, które kazałyby ograniczyć Boże działanie stwórcze tylko do tych dwóch momentów. Z drugiej strony Pismo Święte również nie ogranicza Boskich aktów stwórczych jedynie do pierwszego stworzenia (prima creatio) i do duszy ludzkiej. Mówi bowiem zarówno o kształtowaniu świata, stworzeniu gatunków jak i pierwszego ciała ludzkiego. Zatem wyznaczone przez Tabaczka granice są zupełnie arbitralne - nie mają podstaw ani w danych naukowych ani przesłankach teologicznych. Wynikają one $\mathrm{z}$ próby podporządkowania wiary chrześcijańskiej teoriom ewolucyjnym. Problem polega na tym, że konsekwentny naturalizm odrzuca również stworzenie świata (w sensie absolutnego początku) a także stworzenie duszy. W efekcie teistyczny ewolucjonizm nie zgadza się w tym punkcie ani z tradycyjną wiarą chrześcijańską ${ }^{8}$ ani z konsekwentnymi teoriami ewolucyjnymi.

\section{PROBLEM POCHODZENIA NOWYCH FORM SUBSTANCJALNYCH}

Jednym z podstawowych elementów klasycznej metafizyki jest podział bytu na substancję i przypadłości. Najprościej rzecz ujmując, substancja to to, czym byt jest, natomiast przypadłości to jego cechy, czyli jaki jest. Konsekwentnie możemy wyróżnić dwa rodzaje zmian - substancjalną, czyli taką, w której zmienia się istota (substancja lub natura) bytu (byt przestaje

\footnotetext{
${ }^{8}$ Przez tradycyjną wiarę chrześcijańską rozumiemy tutaj nauczanie Kościoła na temat stworzenia tak jak było one prezentowane przed epoką teistycznego ewolucjonizmu, czyli do początku XX wieku. Nauczanie to zostało wyrażone w traktacie teologicznym De Deo creante (często tytułowanym De Deo creante et elevante, gdyż włączano do niego naukę o grzechu pierwodorodnym). Zręby tego nauczania znajdziemy u autorów takich jak Camillo Mazzella, Joseph Pohle, Christian Pesch, P. Boyer, P. Mannens, Adolphe Tanquerey i innych.
} 
istnieć, a w jego miejsce pojawia się nowy byt), oraz zmianę przypadłościową, czyli taką, w której byt pozostaje tym, czym jest, a zmieniają się jedynie jego przypadłości (czyli cechy i różnorakie określenia). Na mocy definicji zmiana przypadłościowa nie zmienia istoty bytu, czyli nie może sprawić, że dany byt przestaje być sobą. Jeżeli w jakiejś zmianie zostaje utracona istota bytu, to nie jest to już zmiana przypadłościowa, lecz substancjalna.

Ta podstawowa zasada metafizyki arystotelesowsko-tomistycznej stanowi trudność dla teistycznego ewolucjonizmu. Dzieje się tak, ponieważ w ewolucji rozumianej jako naturalny proces przyrodniczy (a tak rozumie się ewolucję $\mathrm{w}$ teistycznym ewolucjonizmie) wszystkie zmiany to jedynie zmiany przypadłościowe. Najczęściej przywoływaną taką zmianą są mutacje genetyczne, które poprzez utrwalenie przez naturalną selekcję miałyby prowadzić do powstawania nowych struktur organicznych, a w końcu także nowych gatunków (pamiętamy, że mówimy tu o nowych taksonomicznych rodzinach, lub tzw. gatunkach naturalnych). Zatem akumulacja szeregu zmian przypadłościowych w kolejnych pokoleniach miałaby zakończyć się zmianą substancjalną. Jednak w świetle metafizyki tomistycznej to jest niemożliwe, ponieważ zmiany przypadłościowe pozostają zawsze na poziomie przypadłości i nie mogą wytworzyć nowej natury. Teistyczny ewolucjonizm albo popada w logiczną sprzeczność (uznając, że zmiana przypadłościowa jest jednocześnie substancjalną), albo zupełnie neguje istnienie substancji w ścisłym metafizycznym sensie. Na taki problem napotyka właśnie propozycja Tabaczka, który ewolucję wyjaśnia następująco:

Zmianę ewolucyjną możemy rozumieć jako serię, utrwalonych przez dobór naturalny, przypadłościowych (akcydentalnych) zmian w strukturze materiału genetycznego (DNA), które mają odzwierciedlenie w morfologii i fizjologii danego organizmu, czy też linii organizmów danego gatunku. Ich efektem jest stopniowa zmiana dyspozycji MP [materii pierwszej] ${ }^{9}$, prowadząca do konkretnego momentu, w którym MP formowana przez FS [formę substancjalną] komórki jajowej oraz FS - przy zmianie substancjalnej będącej skutkiem ich połączenia się ze sobą — nie jest w dyspozycji do bycia uformowaną przez FS rodziców należących do gatunku $\mathrm{G}_{1}$ plemnika, lecz $\mathrm{w}$ dyspozycji do bycia uformowaną przez FS nowego/innego gatunku $\mathrm{G}_{2}$. forma ta jest wyprowadzona (educedi — od łac. educare) z możności (potencjalności) MP. (s. 235)

\footnotetext{
${ }^{9}$ Należy zauważyć, że Tabaczek nieprecyzyjnie posługuje się tutaj pojęciem materii pierwszej. Materia pierwsza posiadająca dyspozycję, to materia określona (materia designata) i taka właśnie materia tworzy byt jednostkowy w połączeniu $\mathrm{z}$ formą.
} 
Warto zaznaczyć, że zaproponowane tutaj rozwiązanie nie wnosi istotnej nowości do dyskusji na temat Tomasza i ewolucji. Już niemal sto lat temu to samo zaproponował Charles De Koninck, a w ostatnich czasach argument ten zmodyfikował i wyciągnął $\mathrm{z}$ niego ostateczne konsekwencje Michael Bolin $^{10}$. Ponieważ Tabaczek dodaje do tego zasadniczo metafizycznego argumentu pewne elementy biologiczne moją odpowiedź podzielę na dwie części - najpierw zajmę się filozofią (a) a później biologią (b) zawartą $\mathrm{w}$ tym argumencie.

\section{A. FILOZOFICZNE PROBLEMY ZAPROPONOWANEGO ROZWIĄZANIA}

\section{A1. Błędne rozumienie substancji}

Tomiści twierdzący, że nowe formy substancjalne mogą powstać poprzez zmianę przypadłościową popełniają jeden z dwóch błędów. Oba błędy wynikają z niewłaściwego rozumienia tego, czym dla Tomasza jest forma substancjalna.

W pierwszym przypadku tomistyczni ewolucjoniści mówią mniej więcej tak: „Jeżeli utniemy kurczakowi głowę, to dokonujemy zmiany przypadłościowej, a jednak prowadzi ona do zmiany substancjalnej, gdyż istota kurczaka zostaje utracona. Kurczak zamienia się w kurze mięso, czyli zupełnie inną naturę. Najwyraźniej zmiana przypadłościowa może więc prowadzić do zmiany substancjalnej". Jednak w tym przypadku dochodzi do pomylenia formy substancjalnej (czyli gatunkowej) z formą indywidualną danego bytu. W istocie zabicie danego kurczaka nie zmienia w żaden sposób kurzego gatunku. Wywołuje jedynie utratę formy substancjalnej kurczaka, ale istniejącej $\mathrm{w}$ tym konkretnym kurczaku, czyli chodzi tu o formę indywidualną. Różnorakie zmiany przypadłościowe zmieniają formę indywidualną danego bytu, ale to, co trwa niezmienione w tym bycie to jego forma substancjalna, która decyduje o przynależności do gatunku. Jeżeli jednak zmiany w indywiduum pójdą za daleko, tzn. materia utraci proporcjonalność z formą, to forma zaniknie i dany byt przestanie istnieć. Nie prowadzi to jednak do powstania żadnego nowego gatunku, a jedynie do anihilacji jednostki tego określonego gatunku.

Błąd ten popełnia Tabaczek, który wprost odrzuca istnienie formy substancjalnej w poszczególnych indywiduach. W jego ujęciu forma substan-

\footnotetext{
${ }^{10} \mathrm{Na}$ argument ten odpowiadam szczegółowo w CHABEREK, Święty Tomasz, 41, 68-70. Odnośniki do autorów, którzy zaproponowali ten argument, zob. przyp. 13, s. 41.
} 
cjalna istnieje w umyśle Boskim, natomiast w poszczególnych bytach realizuje się jedynie w postaci zmiennych form indywidualnych ${ }^{11}$. Takie ujęcie jest bliższe Platonowi, ale w ujęciu arystotelesowsko-tomistycznym forma substancjalna danego gatunku istnieje realnie w każdym indywiduum. Na tym właśnie polega differentia specifica podejścia tomistycznego, które nazywamy umiarkowanym realizmem (wbrew różnego rodzaju idealizmom). Zatem w celu uzgodnienia ewolucji z metafizyką Tabaczek de facto porzuca metafizykę tomistyczną, gdyż umiarkowany realizm, czyli realne istnienie gatunków w indywiduach, stanowi sam rdzeń tej metafizyki i jej podstawowe założenie poznawcze.

W drugim przypadku tomistyczni ewolucjoniści mówią mniej więcej tak: „Jeżeli weźmiemy wodę i dodamy soli, to otrzymujemy solankę. Dodanie soli jest zmianą przypadłościową, jednak woda i solanka to dwie różne substancje." Takich przykładów można podać wiele. Zamrożenie wody spowoduje zamianą wody w lód, a odpowiednie reakcje nuklearne zamienią atom ołowiu $\mathrm{w}$ atom złota. $\mathrm{Z}$ kolei Tabaczek podaje przykłady zmiany siarki w dwutlenek siarki a dwutlenku siarki w siarkowodór (s. 231) ${ }^{12}$. Wszystko to są zmiany przypadłościowe. Zatem najwyraźniej zmiana przypadłościowa może prowadzić do powstania nowej substancji.

Jednak w tym przypadku ewolucjoniści zapominają o analogicznym sensie substancji i mylą ją z rzeczami, które ciężko nazwać substancjami w metafizycznym sensie. Substancja jest tym, co jest najbardziej określone, najbardziej oddzielone i niepodzielne. Dlatego w najprawdziwszym sensie substancją jest tylko Bóg, który jest najbardziej prosty, niepodzielny, określony, oddzielony i najbardziej jest. Wszystko inne jest substancją jedynie przez uczestnictwo. Tomasz uznaje hierarchię substancji, która w porządku zstępującym rozciąga się od aniołów przez człowieka, zwierzęta, rośliny do

${ }^{11}$ „W związku z tym należy uznać, że dla Arystotelesa i św. Tomasza z Akwinu gatunki istnieją realnie oraz są nie- zmienne i wieczne w tym sensie, że każdy $\mathrm{z}$ nich jest zdefiniowany w odniesieniu do FS [formy substancjalnej], która decyduje o tym, że dany gatunek jest tym, czym jest, i wykazuje pewne stałe cechy, tj. stałe zasady ruchu i spoczynku (zmienności i stałości), akcji i reakcji. Formy te są realizacją egzemplarycznych idei w umyśle Boga, którym odpowiada określona potencjalność MP [materii pierwszej]. Jednocześnie każdy gatunek istnieje jedynie jako zrealizowany w konkretnych, zanurzonych w czasie, indywidualnych i zmiennych organizmach. Stąd istotowe wewnętrzne cechy gatunków są niezmienne, podczas gdy ich realizacja w przyrodzie jest zmienna i różnorodna (objawia się to na poziomie cech przypadłościowych organizmów należących do tego samego gatunku)" - Chaberek, Św. Tomasz, 236.

${ }^{12} \mathrm{Na}$ poparcie tej tezy Tabaczek cytuje Quaestio disputata de anima 9, co. Ale cytat ten nie ewolucji, ponieważ w tym miejscu Tomasz mówi o ontogenezie natomiast ewolucja biologiczna dotyczy filogenezy. 
związków i elementów. Zatem elementy są substancjami jedynie w bardzo słabym sensie, do tego stopnia, że właściwie nie można ich nazwać substancjami. Są właśnie elementami, czyli zaprzeczeniem substancji, gdyż są najbardziej podzielne, zmieszane i nieokreślone. Prawdziwymi substancjami na poziomie bytów złożonych są dopiero rośliny, a jeszcze ściślej, dopiero gatunki tak zwanych zwierząt wyższych lub tak zwane gatunki doskonałe (Tomasz podaje przykłady lwa i człowieka, można więc wnosić, że chodzi mu o wszystkie ssaki, zapewne również ptaki i gady). Ponieważ elementy nie są substancjami, żadne zmiany zachodzące $\mathrm{w}$ nich nie są ściśle rzecz biorąc zmianami substancjalnymi. Oczywiście w potocznym języku mówimy, że siarka i siarkowodór to różne substancje, ale nie można mylić potocznego użycia słowa substancja z jej metafizycznym znaczeniem. Na poziomie zmian, które zachodzą w elementach i związkach, nie powstaje żadna nowość. Na przykład powstawanie kryształów, które dla teistycznych ewolucjonistów jest chyba najlepszym przykładem tzw. emergencji, nie prowadzi do powstania jakiejkolwiek nowości. W tego typu zmianach ujawniają się jedynie pewne właściwości fizyczne elementów, które są w nich cały czas tyle, że w innych warunkach się nie ujawniają. Natomiast w makroewolucji biologicznej chodziłoby o powstanie zupełnie nowych form substancjalnych takich jak kot, orzeł czy wieloryb. I tego typu nowość nie może zaistnieć na mocy zmiany przypadłościowej. Nowa natura musi powstać jako pewna całość, na mocy aktu stwórczego, od razu, ponieważ jest ona nową substancją w metafizycznym sensie.

$\mathrm{Na}$ marginesie tych rozważań dodajmy, że tomistyczni ewolucjoniści często walczą $\mathrm{z}$ tak zwanym redukcjonizmem $\mathrm{w}$ biologii polegającym na uznaniu organizmów żywych za maszyny, czyli sumę swoich części. Tomiści uznają, że organizmy są czymś więcej, że nie da się ich sprowadzić do sumy części, ponieważ każdy organizm ma niematerialną zasadę swojego działania, którą jest jego forma substancjalna. Zauważmy jednak, że nie da się spójnie twierdzić, że organizmy nie są sumą swoich części i jednocześnie utrzymywać, że powstały na drodze ewolucji, czyli akumulacji drobnych zmian. Jeżeli bowiem o powstaniu nowych gatunków decyduje dodawanie kolejnych elementów biologicznych do starych gatunków, to logicznie wynika z tego, że organizmy są właśnie zbiorem części. Zresztą rzeczony redukcjonizm w biologii wynika właśnie z przyjęcia ewolucji jako wyjaśnienia powstania różnorodności biologicznej. Zatem tomiści przyjmujący ewolucjonizm nie mają podstaw, aby odrzucać mechanicystyczny redukcjonizm w biologii, ponieważ sami go zakładają. 


\section{A2. Błędne rozumienie dyspozycji materii}

W wywodzie Tabaczka pojawia się także znany od lat argument jakoby nowe formy substancjalne (nowe gatunki) pojawiały się niejako spontanicznie, gdy materia określana przez jedną formę nabędzie dyspozycję do przyjęcia nowej formy ${ }^{13}$. Ponownie argument ten wynika $\mathrm{z}$ błędnego rozumienia hylemorfizmu arystotelesowsko-tomistycznego. Zgodnie z Tomaszem, materia jest aktualizowana przez formę, ale nie $\mathrm{w}$ taki sposób jakoby istniała jakaś dyspozycja materii, która może się zmieniać niezależnie od formy ${ }^{14}$. Pierwszą dyspozycją materii jest jej ilość, ponieważ musi być odpowiednia ilość materii dla danej formy. Ale przecież to nie materia sama siebie określa, lecz forma daje całe określenie (całą aktualność materii). Jeżeli zmienia się dyspozycja i powstaje nowy gatunek, to dlatego, że zmienia się forma. Nie jest więc tak, że w jakimś bycie pod formą niezależnie zmienia się dyspozycja materii aż w końcu materia niejako przyjmie nową formę. Gdyby tak było, to dyspozycja odgrywałaby rolę formy, a forma w ogóle nie byłaby potrzebna. Wypowiedzi Tomasza wprost zaprzeczają rozwiązaniu Tabaczka:

Różnica formy, która wynika jedynie z różnej dyspozycji materii nie powoduje różnicy gatunkowej, lecz jedynie różnicę numeryczną, ponieważ różne jednostki mają różne formy, które są rozróżniane według materii. (STh, I q. 85 a. 7 arg. 3)

Formy nie są konsekwencją dyspozycji materii jako swojej pierwszej przyczyny. Wręcz przeciwnie, materie przybierają dyspozycje stosowne do swoich form. Rozróżnienie zaś rzeczy pod względem gatunku pochodzi od form. Zatem roz-

\footnotetext{
${ }^{13}$ Najprawdopodobniej pierwszy zaproponował to rozwiązanie Charles DE KonINCK, „The Cosmos. The Philosophic Point of View", w: The Writings of Charles De Koninck, red. i thum. Ralph McInerny (Notre Dame, IN: University of Notre Dame Press, 2008), 1:256-321, 278-283.

${ }^{14}$ Świadczą o tym chociażby takie wypowiedzi Tomasza: „Dyspozycje materii pozostają wraz z formą substancjalną” (SS, lib. 1 d. 1 q. 4 a. 2 co.). „Forma i materia muszą być zawsze proporcjonalne względem siebie i jakby naturalnie dobrane, ponieważ właściwe urzeczywistnienie zachodzi we właściwej materii. Zatem materia i forma muszą zawsze zgadzać się ze sobą pod względem jedności i wielości. Jeżeli bowiem istnienie formy zależy od materii, to także pomnażanie jej zależy od materii i podobnie jedność. Jeżeli jednak tak nie jest, to musi zachodzić jakieś pomnażanie formy zgodne z pomnażaniem materii, to znaczy jednocześnie z materią i proporcjonalnie do niej, ale nie w taki sposób jakby jedność lub wielość tej formy zależała od materii” $(C G$, lib. 2 cap. $80 \mathrm{n}$. 8). „Tak długo jak pozostaje dyspozycja materii względem formy pozostaje także forma, ale gdy znika dyspozycja to i forma ginie" (Sentencia libri De anima, lib. 1, 1. 9, n. 13). Należy zwrócić uwagę, że z faktu, że brak dyspozycji w materii wymusza zaginięcie formy nie wynika ani to, że obecność dyspozycji w materii wymusza powstanie formy, ani możliwość spontanicznego powstawania jakichś nowych dyspozycji w materii bez zmiany formy.
} 
różnienie rzeczy nie następuje ze względu na rozróżnienie w materii tak jakby była to pierwsza przyczyna rozróżnienia. ( $C G$, lib. 2 cap. 40 n. 3)

W ujęciu zaprezentowanym przez Tabaczka (patrz schemat na s. 236) nowa forma substancjalna wyskakuje jak królik z kapelusza, gdy tylko materia nabierze odpowiedniej dyspozycji. W poglądzie tym czynnikiem aktywnym (aktualizującym) nie jest już forma jak u Tomasza, lecz materia. Sprowadza się to więc do przekonania, że materia sama kształtuje się w nowe formy. Taki pogląd jest istotą materializmu, ale nie ma nic wspólnego z metafizyką tomistyczną.

Przywołanie w tym kontekście concursus divinus nie rozwiązuje problemu, ponieważ Boże współdziałanie dotyczy porządku opatrzności a nie porządku stworzenia. Concursus divinus wyjaśnia jak Bóg współdziała we wszystkich zdarzeniach naturalnych zachodzących w świecie już uformowanym. Natomiast powstawanie gatunków dotyczy porządku stworzenia, czyli nadprzyrodzonego i bezpośredniego działania Boga mającego na celu uformowanie świata. Zresztą sama koncepcja concursus divinus jest tak samo obca Tomaszowi jak idea creatio continua.

\section{B. NIEZGODNOŚĆ Z ODKRYCIAMI BIOLOGII}

W ujęciu Tabaczka nowe gatunki powstają w wyniku akumulacji wielu mutacji genetycznych:

Proces ten ma charakter poligeniczny, tzn. jest efektem wielu mutacji (których skutki są regulowane doborem naturalnym), a uchwycenie momentu zmiany gatunkowej jest niezwykle trudne, być może wręcz niemożliwe, co nie wyklucza jednak możliwości jej wystąpienia. (s. 236)

Jest faktem stwierdzonym empirycznie, że nowe gatunki biologiczne mogą powstawać w wyniku mikroewolucji, zatem nie ma wątpliwości, że w jakimś bardzo ograniczonym zakresie to ujęcie jest słuszne ${ }^{15}$. Ale, jak już zauważyliśmy, w debacie na temat ewolucji spór nie dotyczy pochodzenia

\footnotetext{
${ }^{15}$ Możliwości i ograniczenia darwinistycznego mechanizmu ewolucyjnego opisał w swoich publikacjach Michael Behe. Podaje on wiele przykładów jak mechanizm ewolucyjny może postąpić parę kroków do przodu i wytworzyć zmianę organiczną, która będzie miała pewne walory adaptacyjne. Jednak Behe pokazuje także dlaczego ten sam mechanizm nie jest w stanie wytwarzać nowych funkcjonalnych białek lub genów. Zob. Michael BeHE, Darwin's Black Box (New York: Free Press, 1996); Bene, The Edge of Evolution (New York: Free Press, 2008); Bene, Darwin Devolves (New York: HarperOne, 2019).
} 
tych drobnych zmian, lecz zupełnie nowych form życia, takich jakie znajdujemy na taksonomicznym poziomie rodzaju lub rodziny. I jeżeli tak zdefiniujemy gatunek, to ujęcie Tabaczka napotyka co najmniej dwa problemy natury biologicznej.

1. Po pierwsze, nie jest prawdą, że jakakolwiek mutacja będzie przyczyniała się do ewolucji. Aby ewolucja mogła zrobić choćby najmniejszy krok, to mutacja musi wywołać przynajmniej taką zmianę, która poskutkuje wzmocnieniem jakiejś funkcji lub powstaniem nowej, korzystnej dla przetrwania organizmu. Tylko wtedy bowiem mutacja będzie widziana przez naturalną selekcję, która rządzi się paradygmatem zachowania tego, co daje przewagę konkurencyjną. Takiej przewagi nie dają byle jakie mutacje. Jak wykazał Michael Behe, w wielu przypadkach przewaga ta ma charakter względny i wynika ze zniszczenia lub osłabienia jakiejś funkcji. W danych okolicznościach taka mutacja może być „korzystna” (podobnie jak oberwanie lusterek, wyrzucenie siedzeń itp. może sprawić, że samochód będzie lżejszy i wygra wyścig na krótkim odcinku), ale tego typu mutacje nie prowadzą do powstania żadnych nowości biologicznych. W istocie powodują one degenerację i wymieranie gatunków (dewolucję), którą faktycznie obserwujemy w przyrodzie.

Naukowcy postawili zatem pytanie, jaka mutacja mogłaby pchnąć ewolucję do przodu w taki sposób, aby wytworzyć jakąś nowość biologiczną. Musiałaby to być mutacja, która spowoduje powstanie nowego białka lub nowej funkcji w białku. W tym celu wyszukali dwa relatywnie proste białka (Kbl i BioF) należące do tej samej grupy, to znaczy spełniające rodzajowo tę samą, choć biologicznie różną funkcję. Przejście od jednego takiego białka do drugiego stanowiłoby teoretycznie najkrótszy krok ewolucyjny (tzn. zmiana mniejsza niż ta nie byłaby widoczna dla naturalnej selekcji). Następnie sprawdzili jakie zmiany należałoby wprowadzić do DNA, aby ekspresja genu kodującego $\mathrm{Kbl}_{2}$ zmieniła się na tyle, aby białko spełniało funkcję $\mathrm{BioF}_{2}$. Okazało się, że należałoby dokonać substytucji co najmniej 7 nukleotydów. Wiemy jednak, że w jednym pokoleniu mutacje najczęściej są pojedyncze, rzadziej podwójne, nigdy zaś potrójne. Statystycznie zdarzenie takie mogłoby nastąpić $\mathrm{w}$ bakterii E-coli po $10^{30}$ pokoleń, co znacznie przekracza czas istnienia świata ${ }^{16}$. Zatem mutacja, która miałaby

\footnotetext{
${ }^{16}$ Naukowcy podsumowali swoje badania następująco: „Szacujemy, że około $10^{30}$ lub więcej pokoleń upłynęłoby, zanim innowacja typu bioF, która jest paralogiczna do kbl, mogłaby zostać wywołana. Oznacza to, że tego typu innowacja znajduje się daleko poza możliwościami dostępnymi w czasie, w którym istnieje życie na Ziemi, przyjmując korzystne założenia. W rzeczywi-
} 
wywołać powstanie najmniejszej nowości biologicznej istotnej z punktu widzenia powstawania gatunków nie mogłaby nigdy nastąpić.

Drugi przykład to badania nad sekwencjami aminokwasów dającymi funkcjonalne białka. Okazuje się, że spośród wszystkich możliwych sekwencji te funkcjonalne, czyli mające jakiekolwiek znaczenie biologiczne, są bardzo rzadkie, rzędu 1 na $10^{77}{ }^{17}$. Co to oznacza? To mniej więcej, tak jakby każdy atom w całym wszechświecie symbolizował chemicznie możliwą strukturę, ale tylko jeden atom w całym świecie miałby jakąkolwiek funkcję biologiczną. (Oczywiście takich funkcjonalnych struktur jest dużo więcej, ale to dlatego, że chemicznie możliwych struktur jest o wiele więcej niż atomów w świecie). Co mówią nam te badania o twierdzeniu Tabaczka, jakoby gatunki różniły się tylko minimalnie, w taki sposób, jakoby przejście od jednego do drugiego stanowiło moment „nieuchwytny empirycznie”? Badania naukowe pokazują coś wręcz przeciwnego. Między gatunkami zionie przepaść możliwych struktur organicznych, które jednak nie mogą tworzyć żywych organizmów. To samo zostaje potwierdzone w makroskali, na poziomie gatunków. W zapisie kopalnym nie znajdujemy bowiem „gatunków pośrednich". Gatunki pojawiają się jakby znikąd, we w pełni ukształtowanej postaci i trwają niezmienione na przestrzeni milionów lat swojego istnienia (staza). Dane naukowe zaprzeczają zatem teoretycznym założeniom na temat stopniowego przekształcania się jednych gatunków w inne a tym samym czynią teistyczną ewolucję koncepcją teologiczną rozmijającą się z faktami.

2. Po drugie mutacje genetyczne nie mogą zmienić całości organizmów, czego wymagałaby makroewolucja, ponieważ DNA nie jest jedynym źródłem informacji w komórce. DNA zasadniczo dzieli się na regiony kodujące i regulujące. Regiony kodujące dostarczają komórkom informację, jak budować białka, natomiast regiony regulujące - w jakich ilościach i kiedy na-

stości, nawet akceptując nierealistycznie korzystne założenia, że duplikaty kbl nie pociągają żadnych kosztów udoskonalenia [fitness cost], przekształcenie pozostaje poza granicami fizycznych możliwości” - Douglas Axe, Anne K. Gauger, „The Evolutionary Accessibility of New Enzyme Functions: A Case Study from the Biotin Pathway”, Bio-complexity, nr 1 (2011): 1-17.

${ }^{17}$ Douglas AxE, „Estimating the Prevalence of Protein Sequences Adopting Functional Enzyme Folds", Journal of Molecular Biology 341, nr 5 (2004): 1295-1315. Należy wyjaśnić, że badania Axe dotyczyły dość wąskiej grupy fałdowań białkowych prowadzących do aktywnych enzymów. Ale sam autor wskazuje na bardziej ogólne wnioski wypływające z tych odkryć. Z punktu widzenia naszego argumentu nie ma znaczenia jaki stopień ekstrapolacji można by przyjąć dla tych badań, ponieważ nawet zawężenie wniosków jedynie do faktycznie przebadanych struktur wywołuje trudność, która stanowi istotę naszego argumentu. Wynika to z faktu, że wszystkie organizmy żywe wyższych gatunków potrzebują wielu aktywnych enzymów do spełniania podstawowych funkcji życiowych. 
leży je budować. Ale to tylko początek procesu życiowego. Można by to porównać do budowy domu: DNA informuje, ile i jakiego materiału należy dostarczyć na plac budowy, jednak nie mówi, jak ten materiał uporządkować w strukturę trójwymiarową. Jak pisze Stephen Meyer:

Inne źródła informacji muszą pomagać w ułożeniu poszczególnych białek w systemy białek, systemy białek w odrębne rodzaje komórek, rodzaje komórek w tkanki, a różne tkanki w organy. Natomiast różne organy i tkanki muszą być ułożone tak, aby utworzyć różne plany ciał ${ }^{18}$.

Ostatecznie nie ma więc znaczenia, ile i jakie mutacje będą zachodzić w DNA, ponieważ nawet nieskończona ilość mutacji nie wytworzy informacji epigenetycznej niezbędnej do rozwoju i życia każdego organizmu. W kontekście tych odkryć upada cała genocentryczna, redukcjonistyczna optyka ewolucjonizmu biologicznego.

Zauważmy, że w teistycznym ewolucjonizmie najczęściej zakłada sie, że ta koncepcja jest lepsza, ponieważ zgodna z nauką. Jednak autorzy tego nurtu, jeżeli w ogóle odnoszą się do badań naukowych, to tylko do takich, które mówią o drobnych zmianach w obrębie gatunków. Nie przywołują badań, które potwierdzałyby zachodzenie makroewolucji ${ }^{19}$. Można więc zastanawiać się, czy koncepcja ta jest zgodna z nauką, czy może jedynie z

\footnotetext{
${ }^{18}$ Stephen C. Meyer, Darwin's Doubt: The Explosive Origin of Animal Life and the Case for Intelligent Design (New York: HarperOne, 2013), 276-277.

${ }^{19} \mathrm{Na}$ przykład Nicanor Austriaco, główny autor wspomnianej pozycji Ewolucja $w$ świetle wiary, powołuje się na własne eksperymenty, w których w wyniku serii skoordynowanych mutacji można sprawić, że jaszczurka w fazie rozwojowej nie wytworzy pary kończyn. Badania te, zdaniem Austriaca, mają pokazywać, jak ewolucja mogła doprowadzić do powstania pierwszych węży z jaszczurko-podobnych przodków. Jednak badania te, choć pokazują istotną rolę genów w niektórych funkcjach biologicznych oraz współczesne możliwości manipulacji genetycznej, nie obrazują makroewolucji z co najmniej trzech powodów. Po pierwsze, mutacje te są serią skoordynowanych mutacji, gdzie biologowie działają w określonym kierunku a w całym procesie uszkodzone jaszczurki są sztucznie podtrzymywane przy życiu i sztucznie rozmnażane. Zatem tego typu zmiany nie mogłyby zajść poza laboratorium, bez wyspecjalizowanego sprzętu i inżynierów genetycznych kierujących każdym krokiem procesu. Po drugie, efekt końcowy, czyli mutanty, nie są zdolne do samodzielnego życia, więc nie mogłyby stanowić żadnych ogniw ewolucyjnych. Po trzecie, utrata kończyn stanowi najwyżej przykład dewolucji, czyli zubożenia biologicznego, a nie powstawania jakichkolwiek nowości biologicznych. Eksperymenty Austriaca potwierdzają to, o czym mówi klasyczna metafizyka — zmiany przypadłościowe w jaszczurce doprowadzą albo do zmutowanej jaszczurki albo do martwej jaszczurki (jeżeli ilość zmian sprawi, że materia straci proporcjonalność z formą). Nigdy natomiast nie przekształcą jaszczurki w inny gatunek naturalny, taki jak wąż. Zob. Nicanor P. G. Austriaco, „In Defense of Thomistic Evolution: A Response to Chaberek", Public Discourse, 7.03.2018, dostęp 16.12.2019, https://www. thepublicdiscourse.com/2018/03/20975.
} 
określoną teorią naukową, lub raczej filozoficzną ideą ewolucjonizmu, w ramach której rozpatruje się dane naukowe nadając im jednostronną interpretację. Na te same dane można spojrzeć inaczej, to znaczy przez pryzmat klasycznej chrześcijańskiej koncepcji stworzenia i nie znajdzie się nic, co byłoby z nią niezgodne. Zatem odrzucenie ewolucjonizmu nie oznacza (jak sugeruje Tabaczek) odrzucenia nauki, lecz jedynie zanegowanie jednej teorii proponowanej w nauce, która niezbyt dobrze pasuje do znanych faktów.

\section{KONKLUZJA}

Teistyczny ewolucjonizm rozpowszechnił się w kręgach tomistycznych dopiero w połowie ubiegłego wieku. Wcześniej tomiści zgodnie bronili klasycznej nauki o stworzeniu opierając się na klasycznej metafizyce Akwinaty. Dopiero, gdy kultura świata zachodniego została zdominowana przez paradygmat ewolucyjny również tomiści zmienili stanowisko. Zaczęli wtedy promować tezę jakoby naukę Tomasza dało się pogodzić z ideą transformizmu gatunkowego na drodze naturalnej ewolucji. Jednak od samego początku to nowe podejście napotkało trudności wynikające z podstawowych zasad metafizyki arystotelesowsko-tomistycznej. Jak dotąd nie udało się wyjaśnić w ramach tomistycznego ewolucjonizmu, w jaki sposób akumulacja zmian przypadłościowych na przestrzeni rozwoju ewolucyjnego miałaby prowadzić do powstawania nowych form substancjalnych. Wyjaśnienia tego problemu nie znajdziemy również w pracach współczesnych tomistycznych ewolucjonistów. Na tym etapie należy więc uznać, że nauki Tomasza nie da się pogodzić z ideą makroewolucji biologicznej. W istocie idea ta uderza nie tylko w jakieś szczegółowe doktryny Arystotelesa lub Tomasza, lecz w same podstawy klasycznej metafizyki. W teistycznym ewolucjonizmie neguje się bowiem zarówno złożenia bytowe (np. substancja-przypadłości) jak i samą zasadę umiarkowanego realizmu będącą fundamentem całej filozofii arystotelesowsko-tomistycznej.

Jednocześnie trzeba zaznaczyć, że celem tego artykułu nie jest ocena ani prawdziwości metafizyki tomistycznej ani słuszności koncepcji teistycznego ewolucjonizmu. Pytanie badawcze dotyczyło zgodności metafizyki tomistycznej z metafizyką, na której opiera się teistyczny ewolucjonizm. Wykazaliśmy fundamentalną niezgodność między tymi dwoma metafizykami. Jednak ocena tego, która $\mathrm{z}$ nich zasługuje na afirmację we współczesnym kontekście kulturowym, naukowym i teologicznym wykracza poza granice tego artykułu. 


\section{BIBLIOGRAFIA}

SKRótowe ODNOŚNIKI DO POWOŁANYCH DZIEŁ TOMASZA Z AKWINU

Tekst łaciński: www.corpusthomisticum.org/iopera.html

De pot Quaestiones disputatae de potentia

CG Summa contra gentiles

STh Summatheologiae

SS Scriptum super Sententiis

\section{PozostaŁe POZYCJE BIBLIOGRAFICZNE}

Austriaco, Nicanor P. G. „In Defense of Thomistic Evolution: A Response to Chaberek”. Public Discourse, 7.03.2018. Dostęp 16.12.2019. https://www.thepublicdiscourse.com/2018/03/ 20975.

Austriaco, Nicanor P. G., James Brent, Thomas Davenport, John B. Ku. Ewolucja w świetle wiary. Perspektywa tomistyczna. Poznań: W drodze, 2019.

AxE, Douglas D. „Estimating the Prevalence of Protein Sequences Adopting Functional Enzyme Folds". Journal of Molecular Biology 341, nr 5 (2004): 1295-1315.

Axe, Douglas D., and Anne K. Gauger. „The Evolutionary Accessibility of New Enzyme Functions: A Case Study from the Biotin Pathway". Bio-complexity, nr 1 (2011): 1-17.

BeHE, Michael J. Darwin Devolves. New York: HarperOne, 2019.

BeHE, Michael J. Darwin's Black Box. New York: Free Press 1996.

BeHE, Michael J. The Edge of Evolution. New York: Free Press 2008.

ChabereK, Michał. „Classical Metaphysics and Theistic Evolution - Why Are They Incompatible?". W: Studia Gilsoniana 8, nr 1 (2019): 47-81.

ChabereK, Michał. „Pochodzenie człowieka. O filozoficznych problemach hominizacji”. W: Spór o początek $i$ koniec życia ludzkiego, 221-255. Lublin: Polskie Towarzystwo Św. Tomasza z Akwinu, 2015.

Chaberek, Michał. Św. Tomasz z Akwinu a ewolucja. Kęty: Marek Derewiecki, 2019.

Chaberek, Michał. „The Five Arguments Stand: Response to a Critic on Aquinas and Evolution”. Evolution News \& Science Today. Dostęp 16.12.2019. https://evolutionnews.org/2018/05/ the-five-arguments-stand-response-to-a-critic-on-aquinas-and-evolution.

ChabereK, Michał. „Tomasz z Akwinu a teistyczny ewolucjonizm”. W: Zeszyty Naukowe KUL 59, nr 1 (2016): 59-82.

De Koninck, Charles. „The Cosmos. The Philosophic Point of View”. W: The Writings of Charles De Koninck, red. i tłum. Ralph McInerny, 1:256-321. Indiana: University of Notre Dame Press, 2008.

Meyer, Stephen C. Darwin's Doubt: The Explosive Origin of Animal Life and the Case for Intelligent Design. New York: HarperOne, 2013.

Tabaczek, Mariusz. Posłowie do Nicanor P. G. Austriaco, James Brent, Thomas DavenPort, John B. Ku, Ewolucja $w$ świetle wiary. Perspektywa tomistyczna, 225-241. Poznań: W drodze 2019. 


\title{
SKĄD POCHODZĄ NOWE FORMY SUBSTANCJALNE? - POLEMIKA Z TEISTYCZNYM EWOLUCJONIZMEM W UJECIU MARIUSZA TABACZKA
}

\author{
Streszczenie
}

Współcześni tomiści usiłują wykazać zgodność metafizyki arystotelesowsko-tomistycznej z teorią makroewolucji biologicznej. W ostatnim czasie stanowisko takie poparł Dr Mariusz Tabaczek. Jednak przyznaje on, że naukę Tomasza należy zmodyfikować w istotny sposób, aby można ją było pogodzić z teistycznym ewolucjonizmem. W jego ujęciu główny punkt takiej modyfikacji stanowi kwestia tego, czy stworzenie się zakończyło, czy nadal powstają nowe gatunki. W istocie ewolucyjny postulat powstawania nowych gatunków uderza nie tylko w naukę Tomasza, ale klasyczne chrześcijańskie rozumienie stworzenia. Tomistyczni ewolucjoniści nie potrafią wyjaśnić pochodzenia nowych form substancjalnych. Odwołują się do zmian przypadłościowych, takich jak przypadkowe mutacje genetyczne, których kumulacja miałaby prowadzić do powstania nowych gatunków. To jednak nie jest możliwe w świetle metafizyki tomistycznej, ponieważ zmiana przypadłościowa nie tworzy nowej substancji. Dodatkowo koncepcja tomistycznych ewolucjonistów nie harmonizuje z wieloma faktami odkrywanymi przez współczesną biologię. Tomistyczni ewolucjoniści muszą porzucić fundamentalne pojęcia filozofii św. Tomasza, takie jak złożenie bytowe substancja-przypadłości czy umiarkowany realizm. Nie da się więc pogodzić makroewolucji biologicznej z nauką Akwinaty.

Słowa kluczowe: tomizm; ewolucja teistyczna; forma substancjalna; makroewolucja.

\section{WHERE DO THE SUBSTANTIAL FORMS COME FROM? - A POLEMIC WITH THE THEISTIC EVOLUTIONISM OF MARIUSZ TABACZEK}

\section{S u m m a r y}

Contemporary Thomists strive to demonstrate a compatibility between Aristotelian-Thomistic metaphysics and the theory of biological macroevolution. Recently such positions have been promoted by Dr Mariusz Tabaczek. However, he admits that Aquinas's teachings need to be substantially modified to make them compatible with theistic evolution. On his view, the main point of controversy is whether the creation of the world has been completed (as Aquinas maintains) or it continues (as it is required by theistic evolution). But the evolutionary postulate of continual creation understood as emergence of totally new substantial forms contradicts not only Aquinas's doctrine but the classic Christian understanding of creation. Thomistic evolutionists cannot explain the origin of new substantial forms; they refer to accidental changes, such as random genetic mutations, whose accumulation over time would produce new species. This, however, is not possible in the light of Thomistic metaphysics because an accidental change does not produce a substantial change. Additionally, the Thomistic evolutionist concept does not tally with many facts discovered by contemporary science. Thomistic evolutionists abandon the fundamental concepts of Aquinas's philosophy such as the substance-accidents fold and moderate realism as a cognitive attitude. Hence the conclusion that it is not possible to reconcile biological macroevolution with Aquinas's teachings.

Keywords: Thomism; theistic evolution; substantial form; macroevolution. 